\title{
Analysis of Service Quality using Service Quality and Importance Performance Analysis Methods in LION SUPER INDO Company
}

\author{
Akmal Suryadi, Farida Pulansari ${ }^{1}$, Moch Sudhafi \\ Department of Industrial Engineering \\ Universitas Pembangunan Nasional "Veteran" Jawa Timur \\ Surabaya, Indonesia \\ 1pulansari@gmail.com
}

\begin{abstract}
To fulfill customer satisfaction, the company must have strategies for managing services properly. The strategies are meant that can affect customer satisfaction, image, and loyalty. Public lack of confidence in the Lion Super Indo Company caused by services is still not good enough. Complaints that arise from consumers such as toilet facilities, parking areas, layout shelf display products that are less organized and clearly, the selling goods are incomplete and operational supermarket is not on time. The research objective is to determine the attributes that affect the quality of service. To analyze the service quality attributes priority, we use five main dimensions i.e. Tangibles, Reliability, Responsiveness, Assurance, Empathy, and IPA method (Importance-Performance Analysis). Based on the results obtained from the data quality level of services provided showed that quality of service is not satisfactorily. Seen from the results of the overall gap is 0.18 to be in the range of values from 0.00 to 0.34, which means not satisfied. The attributes are still not good that attribute toilet facilities and parking areas are available (A2) with the Gap value of $\mathbf{- 0 . 0 5}$, layout shelf display products that are less organized and clearly (A4) with the Gap value of $\mathbf{- 0 , 0 8}$, the selling goods are complete with the Gap value of -1 , The operational supermarket is on time (B1) with the Gap value of 1,06 .
\end{abstract}

Keywords- Service Quality, Importance Performance Analysis, Satisfaction

\section{INTRODUCTION}

Generally, business competitive can change very quickly, dynamically and intricately. Companies must be able to compete in showing excellence in the products or services compared to their competitors. In other hand, [1] conclude that rise of a new paradigm shift from competition to coopetition to increasing levels of service competition in many industries.

Modern markets (retail) that are developing now provide many alternatives to consumers as a place to shop. At this time, the retail stores have begun development in Indonesia. For that situation emerging countries' businesses are trying to improve their competitiveness by implementing innovative branding strategies [2].

Lion Super Indo Company as one of the shopping places that develops its business in order to achieve competitive advantage. Currently, the company in the services is still lacking. The cause being a lot of complaints from customers including the difficulty of getting the desired item, frequent price differences with sanding, inhospitable service, inadequate parking, and inadequate facilities. In addition to the intense competition between several shopping places that are relatively close to each other, the company also has other problems such as frequent out of stock, lack of complete goods sold, price differences between the prices and the switching of old customers to shop elsewhere. Therefore, it is necessary to do research that aims to find out and analyze the level of service quality and proposed improvements that are appropriate based on the level of customer satisfaction.

Service quality (servqual) method is a quality measurement method of service that can find out the aspects of service that need improvement. This method is able to translate customer expectations that are still not fully accommodated by the company, thus requiring an increase in the quality of services provided. There are five dimensions in servqual namely tangible, reliability, responsiveness, assurance and empathy. In this research, we compile Servqual and Importance Performance Analysis (IPA) method. For the first time IPA was introduced by [3]. The cause of expectation discrepancies with customers' perceptions of services is due to the five gaps. IPA is a tool to analyze or use to compare the extent to which the service / performance that can be felt by service users is compared to the desired level of satisfaction. The level of conformity is the result of a comparison between the performance score and the importance score, so that this level of suitability will determine the priority scale to be used in handling. In other hand, According to [4], IPA is a part of marketing research techniques that involve the analysis of customer attitudes toward main product or service.

Finally, the purpose of this paper is to analyze the service attribute that can decrease of customer satisfaction level, image and loyalty. After finding the priority attribute, company can compile the proper company strategy to minimize complaint. Complaint is a signal that indicates an important information from customers and is a major indicator of customer dissatisfaction [5]. While, the research from [6] summarize that customer complaints will give valuable information in the sense that they improve the distribution system and the product performance. To understand customer complaints and identify customers' emotions, companies need to plan recovery strategies to maintain the customer 
satisfaction and loyalty [7]. [8] conduct that migration of profitable customers can be ignored if companies consider complaint as an indicator of some problems or failures in the internal processes that need quick recovery. Finally, as the number of complaints increase, company should devise new strategy to manage them more effectively in order to obtain a positive return on their investments and enhance financial performance [9]

\section{LITERATURE REVIEW}

\section{A. Service Quality}

Service quality can be defined as the expected level of excellence and control over these levels of excellence to fulfill customers. Also, service quality can be defined as everything that focuses on efforts to meet the needs and desires of customers accompanied by accuracy in delivering so a balanced fit with customer expectations is created. Meanwhile, [10] conclude that service quality is one of method that considered as an essential strategy for success and survival. Service is any action or action that can be offered by a party to another party, which is essentially intangible and does not produce ownership. According to [11], there are four service characteristics points, namely: Intangibility (services are abstract) and Intangible (services cannot be seen, touched, heard, or kissed before the service has been received). Second: Variability, services are nonstandard and very variable. Unlike the quality of physical products that have been standardized, the quality of service delivery depends on who provides, when, where and how the service is provided. That's why services are called varied. Third: Inseparability, services are produced and consumed at the same time as customer participation in them. Finally, the last is perishability; services may not be stored in inventory. The value of the service is only available when the service is produced and directly received by the recipient. This characteristic is different from the goods that can be produced first, stored, and used at other times.

\section{B. Importance Performance Analysis (IPA)}

Based on research by [12] reported pointed out that IPA method can develops specific product relations based on attributes of technological priorities and measures customer importance and satisfaction performance. According to [13] conclude that to create high customer satisfaction in managers' service quality improvement project, IPA method is one tool to achieve excellent service quality. In other hand, [14] point out that Importance-Performance Analysis (IPA) is one technique for identifying those attributes of a product or service. This technique is very simple and useful. A research was conducted by $[12,15,16]$ reported that IPA can involves the analysis of customers attitudes towards product/service attributes and direct quality-based perceptions for marketing strategies.

Combination SERVQUAL method and IPA method were constructed to measure the calculation of appropriate weightings for service quality improvement [17].

\section{METHODOLOGY}

To collecting data of service attribute, we use questionnaire survey method. To process the data from the questionnaire, validity test and reliability test used.

Validity test is done by the Pearson method or product moment correlation method, which is by correlating the item scores on the questionnaire with the total score. The measuring trial was conducted on 35 respondents where the respondents were asked to answer the questions. There is a possibility that the question is presented poorly, the arrangement of words or the contents of the sentence which gives rise to different interpretations, so that it needs to be changed. If the correlation coefficient is more than 0.337 then the statement can be said to be valid.

If the measuring instrument has been declared valid, then the reliability of the measuring instrument is tested. Reliability is a term used to indicate the extent to which a measurement result is relatively consistent if the measuring instrument is used repeatedly. In the case of questionnaires, questions in the questionnaire should be made in such a way that if they are repeated by the same respondent, they will also be relatively consistent. Reliability test that has been done using Cronbach's alpha technique is obtained by alpha of 0.983 .

The measurement of service quality in the Servqual model is based on a multi-item scale designed to measure customer expectations and perceptions. As well as the gap between the two in the five dimensions are elaborated in several questions for the attributes of expectations and perception attributes based on the Likert scale, using the following formula: Servqual Score $=$ Perception Score - Expectation Score

Service quality gap scores at various levels in detail can be calculated based on:

a. Item-by-item analysis, for example P1 - H1, P2 - H2, etc. Where $\mathrm{P}=$ Perception and $\mathrm{H}=$ Hope

b. Dimensions -by-dimension analysis, for example: (P1 $+\mathrm{P} 2+\mathrm{P} 3+\mathrm{P} 4 / 4)-(\mathrm{H} 1+\mathrm{H} 2+\mathrm{H} 3+\mathrm{H} 4 / 4)$. Where $\mathrm{P} 1$ to $\mathrm{P} 4$ and $\mathrm{H} 1$ to $\mathrm{H} 4$ reflect the question of perception and expectations related to certain dimensions.

c.Calculation of single size quality / Servqual Gap namely $(\mathrm{P} 1+\mathrm{P} 2+\mathrm{P} 3 \ldots+\mathrm{P} 18 / 18)-(\mathrm{H} 1+\mathrm{H} 2+\mathrm{H} 3 \ldots+\mathrm{H} 18 /$ 18).

\section{DISCUSSION}

After distribute the questionnaire, we found 17 service attribute, which must get the attention of the company.

TABLE I. ATTRIBUTE DESCRIPTION

\begin{tabular}{|c|l|}
\hline Code & \multicolumn{1}{|c|}{ Attribute } \\
\hline A1 & Location is easy to reach \\
\hline A2 & There are supporting facilities such as toilets and parking areas \\
\hline A3 & $\begin{array}{l}\text { The tidiness of the appearance and friendliness of the } \\
\text { supermarket clerk }\end{array}$ \\
\hline A4 & The neat and clear product display rack layout \\
\hline A5 & Complete goods sold \\
\hline B1 & Supermarket operating hours are on time \\
\hline B2 & $\begin{array}{l}\text { Having the cashier serve in a friendly, kind and thorough } \\
\text { manner. }\end{array}$ \\
\hline B3 & Having Produce officers (fruits and vegetables) serving kindly, \\
\hline
\end{tabular}




\begin{tabular}{|c|l|}
\hline Code & \multicolumn{1}{|c|}{ Attribute } \\
\hline & well and thoroughly. \\
\hline B4 & $\begin{array}{l}\text { Having Butcher officer (meat and fish) serve in a friendly, kind } \\
\text { and thorough manner }\end{array}$ \\
\hline B5 & Officer Merchandiser serve kindly \\
\hline B6 & Security officers serve kindly \\
\hline C1 & $\begin{array}{l}\text { The ability of officers to be quick and responsive in resolving } \\
\text { customer complaints }\end{array}$ \\
\hline C2 & Nimble service \\
\hline D1 & Safety in shopping \\
\hline D2 & $\begin{array}{l}\text { Provide product guarantees for products that have been } \\
\text { purchased }\end{array}$ \\
\hline D3 & Quality guaranteed goods (New, decent, and fresh) \\
\hline E1 & Complaints and suggestions are taken seriously \\
\hline
\end{tabular}

Testing the validity of all questionnaire results (respondents' perceptions and expectations) was carried out with the help of SPSS 15 software with the number of respondents at 102 then $\mathrm{df}=102-2=100 ; \alpha=5 \%$, then the $\mathrm{r}$ table is $0.1638 \approx 0.164$ (see table $r$ in appendix $C$ ). Criteria for a data can be declared valid if ( $r$ count $\geq \mathrm{r}$ table).

TABLE II. PERCEPTION VALIDITY TEST

\begin{tabular}{|c|c|c|c|c|}
\hline No. & Attribute & r count & r table & Conclusion \\
\hline 1 & $\mathrm{~A}_{1}$ & 0,415 & 0,164 & Valid \\
\hline 2 & $\mathrm{~A}_{2}$ & 0,537 & 0,164 & Valid \\
\hline 3 & $\mathrm{~A}_{3}$ & 0,570 & 0,164 & Valid \\
\hline 4 & $\mathrm{~A}_{4}$ & 0,446 & 0,164 & Valid \\
\hline 5 & $\mathrm{~A}_{5}$ & 0,465 & 0,164 & Valid \\
\hline 6 & $\mathrm{~B}_{1}$ & 0,373 & 0,164 & Valid \\
\hline 7 & $\mathrm{~B}_{2}$ & 0,454 & 0,164 & Valid \\
\hline 8 & $\mathrm{~B}_{3}$ & 0,737 & 0,164 & Valid \\
\hline 9 & $\mathrm{~B}_{4}$ & 0,513 & 0,164 & Valid \\
\hline 10 & $\mathrm{~B}_{5}$ & 0,430 & 0,164 & Valid \\
\hline 11 & $\mathrm{~B}_{6}$ & 0,737 & 0,164 & Valid \\
\hline 12 & $\mathrm{C}_{1}$ & 0,386 & 0,164 & Valid \\
\hline 13 & $\mathrm{C}_{2}$ & 0,526 & 0,164 & Valid \\
\hline 14 & $\mathrm{D}_{1}$ & 0,466 & 0,164 & Valid \\
\hline 15 & $\mathrm{D}_{2}$ & 0,748 & 0,164 & Valid \\
\hline 16 & $\mathrm{D}_{3}$ & 0,327 & 0,164 & Valid \\
\hline 17 & $\mathrm{E}_{1}$ & 0,570 & 0,164 & Valid \\
\hline & & & Source of information: processing results \\
\hline
\end{tabular}

TABLE III. EXPECTATION VALIDITY TEST

\begin{tabular}{|c|c|c|c|c|}
\hline No. & Attribute & r count & r table & Conclusion \\
\hline 1 & $\mathrm{~A}_{1}$ & 0,508 & 0,164 & Valid \\
\hline 2 & $\mathrm{~A}_{2}$ & 0,340 & 0,164 & Valid \\
\hline 3 & $\mathrm{~A}_{3}$ & 0,508 & 0,164 & Valid \\
\hline 4 & $\mathrm{~A}_{4}$ & 0,448 & 0,164 & Valid \\
\hline 5 & $\mathrm{~A}_{5}$ & 0,345 & 0,164 & Valid \\
\hline 6 & $\mathrm{~B}_{1}$ & 0,508 & 0,164 & Valid \\
\hline 7 & $\mathrm{~B}_{2}$ & 0,384 & 0,164 & Valid \\
\hline
\end{tabular}

\begin{tabular}{|l|l|c|c|c|}
\hline No. & Attribute & r count & r table & Conclusion \\
\hline 8 & $\mathrm{~B}_{3}$ & 0,521 & 0,164 & Valid \\
\hline 9 & $\mathrm{~B}_{4}$ & 0,328 & 0,164 & Valid \\
\hline 10 & $\mathrm{~B}_{5}$ & 0,359 & 0,164 & Valid \\
\hline 11 & $\mathrm{~B}_{6}$ & 0,521 & 0,164 & Valid \\
\hline 12 & $\mathrm{C}_{1}$ & 0,361 & 0,164 & Valid \\
\hline 13 & $\mathrm{C}_{2}$ & 0,448 & 0,164 & Valid \\
\hline 14 & $\mathrm{D}_{1}$ & 0,331 & 0,164 & Valid \\
\hline 15 & $\mathrm{D}_{2}$ & 0,410 & 0,164 & Valid \\
\hline 16 & $\mathrm{D}_{3}$ & 0,440 & 0,164 & Valid \\
\hline 17 & $\mathrm{E}_{1}$ & 0,316 & 0,164 & Valid \\
\hline
\end{tabular}

To test the accuracy of the results of the questionnaire measurement reliability testing was carried out. A test tool is said to have a level of confidence if the test provides the right results. The best amount of reliability is 1 and the worst is 0 . The greater the value obtained, the more reliable the attribute is. If the calculation is not reliable, it needs to be reviewed in the preparation of the questionnaire. Criteria for a data can be expressed reliably if ( $\alpha$ count $\alpha \alpha)$. The results of the complete reliability test processing can be seen in Appendix $B$, the results of the overall summary of both perception and expectations are obtained in Table IV.

\section{TABLE IV. PERCEPTION AND EXPECTATION RELIABILITY} TESTS

\begin{tabular}{|c|c|c|c|c|}
\hline No. & Questionnaire & $\alpha_{\text {count }}$ & $\alpha_{\text {table }}$ & Conclusion \\
\hline 1 & Perception & 0,727 & 0,164 & Reliable \\
\hline 2 & Expectation & 0,721 & 0,164 & Reliable \\
\hline
\end{tabular}

After testing the reliability of perception and expectations of the respondents showed $\alpha$ count $\geq \alpha$ table so the data was reliable, because the perception of the respondents $(0,727>$ $0,164)$ and the expectations of the respondents $(0.721>0.164)$.

\section{ANALYSIS}

1. Value analysis Servqual

The results of the calculation Servqual known that for the calculation of the value of the attribute Gapper, the criteria to be a priority to improve the quality of service is:

a. There are facilities such as toilets and parking area (A2) with the Gap -0.05 , based on the criteria of customer satisfaction score is negative and less than 0 , so are not very satisfactory.

b. Layout display shelf products that neat and clear (A4) with a value of $-0.28 \mathrm{Gap}$, based on the criteria of customer satisfaction score is negative and less than 0 , so are not very satisfactory.

c. Goods sold complete (A5) with the Gap -1, based on the criteria of customer satisfaction score is negative and less than 0sehingga are not very satisfactory. 
d. Operations at the supermarket right time (B1) with the Gap -1,06berdasarkan criteria customer satisfaction score is negative and less than 0 , so are not very satisfactory.

2. Analysis Diagram IPA (Importance Performance Analysis)

\section{a. A quadrant: (Hope> Perception)}

Attributes in quadrant $\mathrm{A}$ are:

- There are facilities such as toilets and parking area (A2) has a value perception $(\mathrm{X})=4.22$ and the expectations $(\mathrm{Y})$ $=4.77$, because the expectation is greater than the value of the perception that these attributes are prioritized for repair.

- Layout display shelf products that neat and clear (A4) has a value perception $(\mathrm{X})=3.98$ and the expectations $(\mathrm{Y})=$ 4.26 , because the expectation is greater than the value of the perception that these attributes are prioritized for repair.

- Goods sold complete (A5) with the perception $(\mathrm{X})=3.75$ and the expectations $(Y)=4.75$, because the expectation is greater than the value of the perception that these attributes are prioritized for repair.

- Hours Operations supermarket right time (B1) has a value perception $(\mathrm{X})=3.71$ and the expectations $(\mathrm{Y})=4.77$, because the expectation is greater than the value of the perception that these attributes are prioritized for repair.

Attributes in this quadrant have a level of expectation that is relatively high but acceptable customer satisfaction is relatively low. Therefore, management should immediately make improvements in performance that can improve the quality of service.

\section{b. Quadrant B: (Hope <Perception)}

Attributes that are in quadrant B are:

- Location dijangkauA1 easily have perceived value $(X)=$ 4.79 and the expectations $(Y)=4.77$, because the expectation is smaller than the value of the perception that the attributes in this quadrant must be maintained.

- The appearance of neatness and friendliness officers supermarket $(\mathrm{A} 3)$ has a value perception $(\mathrm{X})=4.77$ and the expectations $(Y)=4.33$, because the expectations of the value and perception of the attributes that in this quadrant must be maintained.

- Does the clerk serving with friendly, kind and thoughtful. (B2) has a value perception (X) $=4.62$ and the expectations $(\mathrm{Y})=4.38$, because the expectations of the value and perception of the attributes that in this quadrant must be maintained.

Attributes that are in this quadrant should be retained as a Lion Super Indo Company excellence, because of high expectations and perceptions are also high.

c. Quadrant C: (Expectations <Perception)

The attributes of the $\mathrm{C}$ quadrant are:
- Officer Produce (fruits and vegetables) served with friendly, good and conscientious (B3) has a value perception (X) = 4.13 and the expectations $(\mathrm{Y})=4.08$, the expectations of small and also the perception that small attributes in this quadrant should be ignored because it is not too important for the customer.

- Is Security officers serving with friendly and good (B6) has a value perception $(\mathrm{X})=4.13$ and the expectations $(\mathrm{Y})=$ 4.08 , the expectations of small and also the perception that small attributes in this quadrant must not be ignored because too important for customers.

- Services deft $(C 2)$ has a value perception $(X)=4.19$ and the expectations $(\mathrm{Y})=3.95$, the expectations of small and also the perception that small attributes in this quadrant must be ignored because it is not important to the customer.

- Security in the shop (D1) has a value perception $(\mathrm{X})=4.21$ and the expectations $(Y)=4.04$, the expectations of small and also the perception that small attributes in this quadrant must be ignored because it is not important to the customer.

- Provide product warranty for products purchased (D2) has a value perception $(\mathrm{X})=4.14$ and the expectations $(\mathrm{Y})=3.78$, the expectations of small and also the perception that small attributes in this quadrant must not be ignored because too important for customers.

- Goods guaranteed quality (new, fit for consumption, and fresh) (D3) has a value perception $(\mathrm{X})=4.21$ and the expectations $(\mathrm{Y})=3.51$, the expectations of small and also the perception that small attributes in this quadrant should be ignored because it is not too important for customers

In this quadrant of attributes that can be overlooked because of the attention of the management of interest rates and the level of customer satisfaction undervalued

\section{d. Quadrant D: (Expectations <Perception)}

The attributes of the quadrant $\mathrm{D}$ are:

- Is the officer Butcher (meat and fish) served with friendly, good and conscientious (B4) has a value perception (X) = 4.64 and the expectations $(\mathrm{Y})=3.99$, because the expectation is smaller than the value of the perception that must reducing activity that is not important to the customer.

- Is the officer Butcher (meat and fish) served with friendly, kind and conscientious. (C1) with the perception $(\mathrm{X})=$ 4.60 and the expectations $(\mathrm{Y})=3.88$, because of expectations of a smaller value to reduce the perception that the activity is not important to the customer.

- Is Merchandiser officer serving with friendly and good (B5) has a value perception (X) $=4.68$ and the expectations $(Y)=3.97$, because of expectations of a smaller value to reduce the perception that the activity is not important for customers,

- Complaints and suggestions are taken seriously (E1) has a value perception $(\mathrm{X})=4.33$ and the expectations $(\mathrm{Y})=$ 3.94 , because of expectations of a smaller value to reduce 
the perception that the activity is not important to the customer.

For quadrant $\mathrm{D}$ is known that the level of people's expectations of the level of service low but perception shown by the high service. This is most likely due to the agency providing the service that over, so that should reduce activities or save resources for the services that are in this quadrant.

\section{CONCLUSION}

Based on the results of research and discussion that has been done before conclusions can be drawn as follows:

1. The result shows that the services provided by Lion Super Indo Company of the five dimensions of 0.14 so that the level of quality of services rendered less well or not satisfactory because the table is based on the criteria of customer satisfaction is in the range of $0.00-0.34$, which means not satisfied.

2. The quality of service is a priority for improved on. Lion Super Indo attributes that are supporting facilities such as toilets and parking area (A2) with the Gap -0.05, Layout display shelf products neat and clear (A4) with a value of -0.28 Gap, Goods sold complete (A5) with the gap - 1 Hour Operations supermarket right time (B1) with a value gap -1.06

\section{REFERENCES}

[1] X. Chen, Z. Luo, and X. Wang, "Compete or cooperate: Intensity, dynamics, and optimal strategies," Omega, pp. 1-11, 2018.

[2] C. Chailan, F. Ille, "Branding from emerging countries: how to compete internationally?," Critical perspectives on international business, Vol. 11 Issue: 1, pp.54-71, 2015.

[3] J.A. Martilla and J.C. James, "Importance Performance Analysis", Journal of Marketing, Vol. 41 (1), pp. 77-79, 1977

[4] F.d.J.H.Silva and P.O.Fernandes, "Importance-Performance Analysis As A Tool In Evaluating Higher Education Service Quality: The Empirical
Results Of ESTiG (IPB)", Creating Global Competitive Economies, A 360-Degree Approach', pp.306-315, 2011.

[5] C.-H.Lee, Y.-H. Wang and A. J. C. Trappey, "Ontology-based reasoning for the intelligent handling of customer complaints". Computers \& Industrial Engineering, Vol.84, pp.144-155, 2015

[6] W. Wagner, "Managing Customer Complaints in Distribution", International Journal of Physical Distribution \& Logistics Management, Vol.24, No.4, pp.1994, 11-17, 1994.

[7] C. Varela-Neira, R. Vasquez-Casielles, and V. Iglesias, "Explaining Customer Satisfaction with Complaint Handling",. International Journal of Bank Marketing, Vol.28, No.2, pp.88-112, 2010.

[8] A. Filip, "Complaint management: A customer satisfaction learning process", Procedia - Social and Behavioral Sciences, Vol. 93, pp.271$275,2013$.

[9] J. Cambra-Fierro, I. Melero, and F. J. Sese, "Managing Complaints to Improve Customer Profitability", Journal of Retailing, Vol. 91, pp.109124, 2015.

[10] P. Ramseook-Muhurrun, S.D. Lukea-Bhiwajee and P. Naidoo, " Service Quality in the Public service", International Journal of Management and Marketing Research, Vol 3, No. 1, pp.37-50, 2010.

[11] P. Kotler, and G. Armstrong, "Prinsip-prinsip Pemasaran", $13^{\text {th }}$ Edition. Jakarta, Erlangga, 2012.

[12] S.E. Sampson and M.J.Showalter, "The Performance-Importance Response Function: Observations and Implications", Service Industries Journal, Vol.19, No.3, pp.1-25, July 1999.

[13] P. Gemmel, "Delivering Excellent Service Quality in Aviation: A Practical Guide for Internal and External Service Providers", International Journal of Service Industry Management, Vol.18, pp.443444, 2007.

[14] J. Abalo, J. Varela, and V. Manzano, "Importance values for Importance Performance Analysis A formula for spreading out values derived from preference rankings", Journal of Business Research, Vol. 60, pp.115121.

[15] H. Wu, Y. Tang and J. Shyu, "A case of applying importanceperformance analysis in identifying key success factors to develop marketing strategies", Journal Quality and Quantity, pp. 1573-7845, 2009.

[16] R. Lewis, "Importance-Performance Analysis", in Australasian Journal of Engineering Education, pp.1-8. 2004.

[17] G-H. Tzeng and H-F. Chang, "Applying Importance-Performance Analysis as a Service Quality Measure in Food Service Industry", Journal of Technology Management \& Innovation, Vol.6, No.3, Januari 2011. 